\title{
THE INFLUENCE OF OXIDIZING AND REDUCING CONDITIONS UPON THE DISTRIBUTION OF SOME ELEMENTS IN LAKE SEDIMENTS ${ }^{1}$
}

\author{
Eville Gorham \\ Department of Botany, University of Minnesota, Minneapolis \\ and \\ Dalway J. Swaine \\ C.S.I.R.O. Division of Coal Research, Chatswood, N. S. W., Australia

\begin{abstract}
ABSTR $\Lambda$ CT
Analyses for $\mathrm{Fe}, \mathrm{Mn}, \mathrm{Pb}, \mathrm{Zn}, \mathrm{Co}, \mathrm{P}, \mathrm{Mo}, \mathrm{Ba}, \mathrm{Sr}, \mathrm{Ti}, \mathrm{Li}, \mathrm{Rb}, \mathrm{Na}, \mathrm{K}, \mathrm{Be}, \mathrm{Cr}, \mathrm{V}, \mathrm{Y}, \mathrm{Ag}$, $\mathrm{Cu}, \mathrm{C}, \mathrm{S}, \mathrm{Sn}, \mathrm{Ni}, \mathrm{Ga}, \mathrm{Zr}$, and $\mathrm{La}$ have been carried out on some oxidate crusts, oxidized surface muds, reduced subsurface muds, and glacial clays collected in Windermere and Esthwaite Water in the English Lake District. The relatively organic lake muds exhibit the highest concentrations of $\mathrm{C}, \mathrm{S}, \mathrm{Cu}, \mathrm{Sn}$, and Ni. Many of the oxidate crusts exhibit strong enrichment in $\mathrm{Mn}, \mathrm{Fe}, \mathrm{Ba}, \mathrm{Sr}, \mathrm{Pb}$, and $\mathrm{Zn}$. Ti, $\mathrm{Li}, \mathrm{Rb}, \mathrm{Co}, \mathrm{P}$, and $\mathrm{Mo}$ are also enriched in some crusts. $\mathrm{S}, \mathrm{Sn}$, and $\mathrm{Ni}$ reach their highest levels in the reducing subsurface muds, but $\mathrm{Mn}$, and to a lesser extent $\mathrm{Fe}$ and $\mathrm{Mo}$, are higher in the oxidized than in the reduced muds.

Relations between the elements in the various sediments are examined, and the English oxidate crusts are compared with lake and stream ores in Sweden and Finland, and with marine manganese nodules. These marine nodules are frequently enriched in $\mathrm{Cu}, \mathrm{Ni}, \mathrm{Co}$, Mo, V, Ag, and Sn to a far higher degree than the freshwater ferromanganese concretions. Some freshwater crusts exhibit enrichments in $\mathrm{Pb}, \mathrm{Zn}$, and $\mathrm{Ba}$ of the same order as those observed in marine manganese nodules.
\end{abstract}

\section{IN'TRODUCTION}

One of the most important factors affecting the exchange of dissolved substances between mud and water in lakes is the redox potential gradient in the system (Mortimer 1941-1942; Hutchinson 1957; Gorham 1958). Little is known, however, of the effects of redox potential upon the total chemical composition of lake sediments, and the present study was undertaken to investigate this question.

The main object was to compare the elemental composition of oxidizing and reducing muds from the uppermost layers of sediment in Esthwaite Water and Win-

\footnotetext{
1 This work was done while the first author was at the Freshwater Biological Association, Ambleside, Fngland, and the second was at the Macaulay Institute for Soil Research, Aberdeen, Scotland. They are grateful to Mr. F. J. H. Mackereth, Mr. J. Heron, and the laboratory staff of the Freshwater Biological Association for advice and assistance, and to Dr. R. L. Mitchell of the Macaulay Institute for Soil Research for allowing the spectrographic analyses to be made in his laboratory and for reading the manuscript. Contribution No. 20, Limnological Research Center, University of Minnesota.
}

dermere in the English Lake District. In the course of the study several ferromanganese "oxidate crusts" were discovered in Windermere and Ullswater, and these too were examined, together with three samples of glacial clay found under a thin layer of mud at the site of the first "crust" discovery. ${ }^{2}$ Information regarding Windermere and Esthwaite Water is given in Table 1.

\section{METHODS}

\section{Sampling}

Samples of undisturbed surface mud were collected in October and November of 1954 using a Jenkin surface mud sampler (Mortimer 1941-1942, Fig. 22). Subsamples were taken with a stainless steel spoon from the surface, 5 , and $10 \mathrm{~cm}$ depths of the mud in these cores and placed in polyethylene bottles (cleaned with dilute chromic-sulfuric acid and immediately

\footnotetext{
${ }^{2}$ These crusts were first found in Windermere some years ago by Professor H. P. Moon, and are known by the staff of the FBA Laboratory there as "Moon Crust."
} 
TABLE 1. Some characteristics of Windermere North Basin and Esthwaite Water*

\begin{tabular}{|c|c|c|}
\hline & $\begin{array}{l}\text { Windermere, } \\
\text { North Basin }\end{array}$ & $\begin{array}{l}\text { Esthwaite } \\
\text { Water }\end{array}$ \\
\hline Area $\left(\mathrm{km}^{2}\right)$ & 8.2 & 1.0 \\
\hline Mean depth (m) & 26 & 6.8 \\
\hline Maximum depth (m) & 67 & 16.1 \\
\hline Rocks of drainage basin & $\begin{array}{l}\text { Hard volcanics and some } \\
\text { Silurian sedimentaries }\end{array}$ & $\begin{array}{l}\text { Mainly Silurian sedimen- } \\
\text { taries (slates, grits, } \\
\text { flags) }\end{array}$ \\
\hline Phytoplankton productivity & Moderate & Relatively high \\
\hline Aeration of bottom water and mud surface & Continuously oxygenated & Anoxic in late summer \\
\hline $\begin{array}{l}\text { Oxygen absorption by mud in summer } \\
\left(\text { gm m }^{-2} \text { day }^{-1}\right)\end{array}$ & 0.52 & 0.65 \\
\hline $\begin{array}{l}\text { Winter thickness of oxidized surface mud } \\
\text { layer }(\mathrm{cm})\end{array}$ & 1.1 & 0.7 \\
\hline $\begin{array}{l}\text { Winter redox potential }\left(\mathrm{E}_{7}\right) \text { at } 5 \mathrm{~cm} \text { depth } \\
\text { (volts) }\end{array}$ & -0.05 & -0.07 \\
\hline Calcium & 0.27 & 0.41 \\
\hline Magnesium & 0.07 & 0.12 \\
\hline Sodium & 0.16 & 0.20 \\
\hline (meq/liter in surface lake waters) & 0.01 & 0.02 \\
\hline Bicarbonate & 0.17 & 0.31 \\
\hline Sulfate & 0.14 & 0.20 \\
\hline Chloride & 0.17 & 0.20 \\
\hline
\end{tabular}

* Data from Mortimer (1941-1942) and Gorham (1960).

rinsed in five changes of tap and 10 of distilled water). The crust from the Wray Castle location (Boathouse Bay) was collected during the same period, together with samples of the thin surface mud layer and the glacial clay underlying it. The other crusts were collected at various times.

\section{Analysis}

The samples were dried and ground in an agate mortar. All analyses were made on material dried at 100-110C.

Carbon, mostly organic, was determined gravimetrically by dry combustion, free carbonate bcing negligible. Sulfur was estimated by a technique devised by F. J. H. Mackereth (unpublished). Phosphorus, iron, and manganese were estimated spectrophotometrically as phosphomolybdate, ferric chloride, and permanganate, respectively, after digesting the sediments with hydrofluoric and perchloric acids. A Unicam SP 500 spectrophotometer was used. Sodium and potassium were determined by EEL flame photometer on diluted subsamples of the same digests.

The remaining elements were estimated semi-quantitatively by the cathode layer arc method (Mitchell 1948). A mixture of equal weights of the finely ground sample and carbon powder was filled into a carbon electrode which was used as the cathode in a $9 \mathrm{amp} \mathrm{d}$-c arc. Two 1-min exposures were taken with a Hilger Large Quartz spectrograph (E492) on each of two plates covering the ranges $2,470-3,550 \AA$ and $3,180-8,000 \AA$. The precision may be about $\pm 30 \%$, but it is usually better than this, especially at low concentrations.

The following elements were not detected, the limits of detection (when known) being given in parentheses as ppm: As $(3,000) ; \mathrm{Au}, \mathrm{Bi}(30) ; \mathrm{Cd}(200) ; \mathbf{H g}$ $(1,000)$; In (10); Ir, Pt, Sb (300); and Tl (10). Ge was possibly present (10? ppm) in three of the Windermere muds $(107,773$ $107,775)$, and Sc (10 ppm) was detected in two of the oxidate crusts $(107,782$ and 107,784) (numbers are those of the Macaulay Institute, where the spectrographic analyses were carried out; the prefix 107 will be omitted).

\section{DESCRIPTION OF SAMPLES}

Samples 761-3 were collected 7 October 1954, in shallow water (approx $4 \mathrm{~m}$ ), from 
mud at the mouth of the Congo Beck, a small stream entering the northwest end of Windermere. The first sample taken from the surface of the core was rusty in color; the second sample, from $5 \mathrm{~cm}$, was brown, and the third, from $10 \mathrm{~cm}$, was blackish brown.

Samples 764-8 and 779 were taken 7 October 1954 from shallow water (approx 3-4 m) in the Wray Castle Boathouse Bay of Windermere. The first of these was from a layer of dark brown mud a few centimeters thick; the second was a number of small pieces of oxidate crust apparently embedded in this mud at its boundary with the clay beneath. The next was a rusty colored clay immediately beneath the mud; a number of soft friable pieces of incipient (or degraded) crust were removed from this sample. The fourth was a whitish clay showing no evidence of iron migration into it. The fifth was greenish clay having the mottled or gleyed appearance characteristic of reducing conditions, although small bits of crust were embedded in it (these were removed). The final sample (779) was composed of large pieces of oxidate crust dredged from this site, probably from the surface mud.

Samples 773-5 were taken from the deepest point (approx $60 \mathrm{~m}$ ) of Windermere 29 November 1954. The first was reddish brown surface mud, the second blackish brown mud from about $5 \mathrm{~cm}$ depth, and the third blackish mud from $10 \mathrm{~cm}$.

Samples 770-2 were taken from the deepest part (approx $16 \mathrm{~m}$ ) of Esthwaite Water on 11 October 1954. The first was surface rusty mud, the second blackish brown mud from $5 \mathrm{~cm}$, and the third more blackened mud from $10 \mathrm{~cm}$ depth.

Samples 776-8 were also from Esthwaite Water, $16 \mathrm{~m}$, but were collected on 29 November 1954. The surface of the first was brown rather than rusty colored, while the second and third, from 5 and $10 \mathrm{~cm}$, were black.

The color of the samples was a guide to their redox potential. The surface samples all exhibited varying degrees of rusty colored ferric hydroxide deposition and were oxidizing. The deeper samples, with varying amounts of black ferrous sulfide precipitates, were all reducing. The autumn and winter redox potentials given for these two lakes by Mortimer (1941-1942), and later measured occasionally by us, support the view that the surface muds are oxidizing and that the subsurface muds are strongly reducing. Mortimer points out that the mud surface in the deep Windermere is permanently oxidizing, while that of Esthwaite becomes reducing each summer owing to de-oxygenation of the bottom waters of this shallow and fertile lake. Thus, sample 770 must have been reducing shortly before collection.

Samples 780-5 were all oxidate crusts. The first was probably collected from Ash Landing on Windermere, and the second was caught in a perch net off Ferry House, Windermere, 14 October 1954. The third was taken in a perch net $100 \mathrm{~m}$ north of Thompson Holm on Windermere, 1 November 1954. Sample 783 was an irregularly shaped crust including many tiny stone fragments, collected from approx 4-5 m depth in Ullswater in October 1954. Sample 785 was collected near the shore of Ullswater at the same time, but was one of a series of more regular and rather saucershaped crusts with raised edges and without stony inclusions. Sample 784 was a clayey crust formed over laminated clay on the Chicken Rocks, Windormere, collected 29 November 1954.

The color of these crusts was generally patchy or layered, pale or reddish brown to purplish brown, but when the samples were finely ground, the colors ranged from pale fawn in the clayey crust from Chicken Rocks (784) to dark chocolate brown in the large pieces of crust from near Wray Castle (779). The depth of brown color (estimated visually on a six-point scale) showed a positive correlation with the manganese content. Sample 765 had a distinctly reddish tint when ground and was exceptionally rich in iron.

From the scant information available about the collection sites, it appears that oxidate crusts are formed where the relatively organic lake mud deposits are thin or absent above the basal glacial deposits, 
that is, where muds accumulate slowly if at all. In such a situation, divalent iron and manganese can be supplied continually to an unchanging surface at which they are oxidized and precipitated. Rock faces at many depths in Windermere sometimes have a thin coat of material resembling oxidate crusts. This phenomenon and the occurrence of such crusts on stones in brooks (Ljunggren 1953) and in lakes (Kindle 1935, 1936) suggests that the iron and manganese which form these crusts may come at least partly from the water and not wholly from the sediment (although the sediment may be the major source whon present). Both elements may be combined with or adsorbed on particulate or soluble organic compounds, and if these were metabolized by surface bacteria, the iron and manganese would become available for crust formation in sites where silting or organic deposition is too slow to bury or again reduce the oxides as they are deposited (Hutchinson 1957, p. 711; Graham 1959; Graham and Cooper 1959).

Another hypothesis of oxidate crust formation on stony or gravelly substrata near the water surface involves photosynthesis by algae (Kindle 1932, 1935) or aquatic bryophytes (Ljunggren 1953), which may precipitate iron and manganese by raising the $p \mathbf{H}$ and oxygen concentration near the surface of the organisms, although this mechanism could not operate in the dark. Zapffe (1931) indicates that after bacteria begin the oxidation of iron and manganese, the aggregates formed catalyze their own accretion. It is also possible that the mechanism is wholly chemical, at least in some sites (Ljunggren 1953; Goldberg and Arrhenius 1958).

Kindle (1936) has reported that in Nova Scotian lakes, manganese crusts usually form on stony or gravelly shores where wave action is strong, and not on the soft and organic bottom muds ( see Aarnio, cited by Ljunggren 1953, for Fennoscandian lakes; Moore 1910 for Ontario lakes; and Zumberge 1952 for Rabbit Lake in Minnesota). It appears that manganese nodules and crusts in the sea are located in areas of slow sedimentation, such as on sea mounts or other elevated features of the ocean floor (Goldberg 1954), with the crusts often forming on exposed rocks (Dietz 1955). Freshwater oxidates must accumulate much more rapidly than marine ones, since Goldberg and Arrhenius (1958) quote a rate of $1 \mathrm{~mm} / 1,000$ years or more in the ocean, while Kindle (1935) indicates that visible coatings may develop on rocks in dammed Nova Scotian lakes within 25 years. Ljunggren (1953, quoting Naumann) states that ore-scraping for economic use could take place about once every 50 years in the ore lakes of southern Sweden.

\section{RESUI,TS}

The mud, clay and oxidate crust analyses are presented in Table 2. The average lithosphere values have been selected from Goldschmidt (1954), Fleischer (1953), Vinogradov (1956), Green (1959), and from recent surveys dealing with specific elements, namely silver (Hamaguchi and Kuroda 1959), chromium (Fröhlich 1960) cobalt (Carr and Turekian 1961), gallium (Burton, Culkin, and Riley 1959), and tin (Onishi and Sandell 1957). Mean values for Scottish soils (Swaine 1951, 1955) are also given.

Comparison of different types of sediment

In comparing the concentrations of different elements in the oxidized and reduced phases of the uppermost lake muds, it appears that generally there is no great enrichment or depletion of either phase. The most marked difference is that shown by $\mathrm{Mn}$, which is 6.5 times as great in the oxidized surface layers as in the reduced muds a few centimeters beneath. Molybdenum is about twice as plentiful in the oxidized phase, which also contains over a third more $\mathrm{Fe}$ than does the reduced phase. Other enrichments appear to be minor, being less than $10 \%$ in all cases except for $\mathrm{P}$ and $\mathrm{Ba}$, where the average enrichment reaches about $20 \%$ but is highly variable in the four sets of samples.

The oxidized muds are poorer in some elements than the reduced subsurface sediments, but the differences are small in most cases. Among the elements showing the 


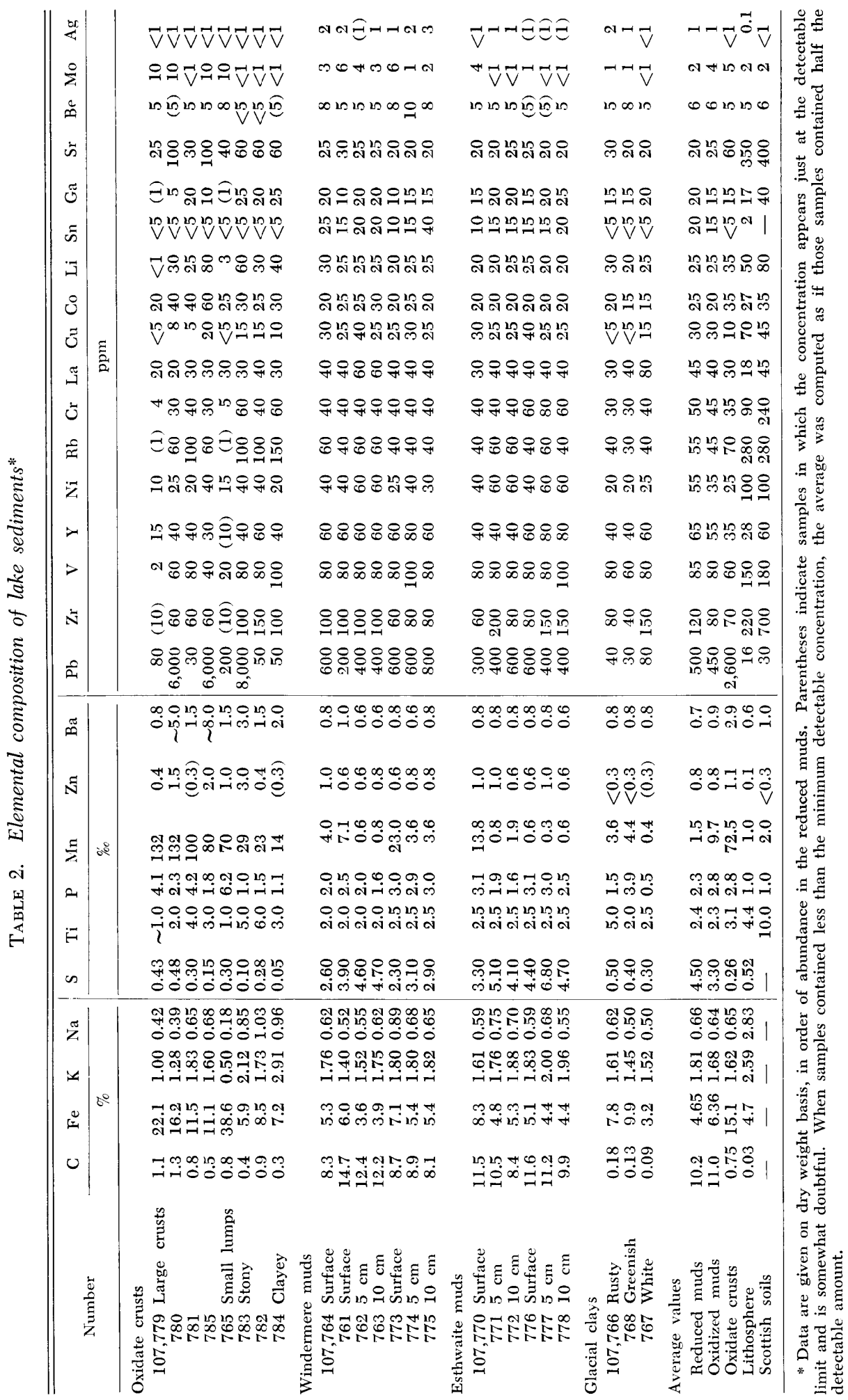


greatest depletion are $\mathrm{Zr}, \mathrm{Ni}, \mathrm{S}, \mathrm{Ga}$, and $\mathrm{Sn}$, which range from 33 to $25 \%$ lower in the oxidized than in the reduced phase.

The sediments, oxidate crusts, and the glacial clay are compared in Fig. 1, which gives a value of 100 to the highest average concentration and proportional values for the average concentrations of the other sediments (one sample only of white clay is included, since the other two were undoubtedly altered by element migration along redox gradients). To illustrate the method, the oxidate crusts have the highest $\mathrm{Sr}$ concentration, averaging $60 \mathrm{ppm}$. The other values are given as percentages of 60 . Elements showing similar distributions among the four kinds of sediment are assembled in the figure. $\mathrm{Fe}, \mathrm{Mn}, \mathrm{Zn}, \mathrm{Co}, \mathrm{Pb}$, $\mathrm{P}$, and $\mathrm{Mo}$ are lowest in the white glacial clay and highest in the oxidate crusts. $\mathrm{Sr}$ and $\mathrm{Ba}$ are much higher in the oxidate crusts than in the other sediments, whereas $\mathrm{V}$ and $\mathrm{Y}$ are distinctly lower. $\mathrm{C}, \mathrm{Cu}, \mathrm{S}, \mathrm{Ni}$, and $S n$ reach maximum levels in the organic muds. $\mathrm{Ga}, \mathrm{Zr}$, and $\mathrm{La}$ are highest in the white glacial clay, and lowest in the oxidate crusts.

\section{Variation among oxidate crusts}

In general, the oxidate crusts vary in composition much more than the muds, where only Mn and Mo show marked variability. Among the most variable crust elements are $\mathrm{Pb}, \mathrm{Rb}, \mathrm{Li}, \mathrm{V}$, and $\mathrm{Ga}$, for which the maximum: minimum ratios of concentration in the crusts are 270, 150, $>80,50$, and 25, respectively. Among the least variable elements are $\mathrm{La}, \mathrm{Co}, \mathrm{Ni}, \mathrm{Sr}$, and $\mathrm{C}$, with ratios of $2,3,4,4$, and 4 , respectively. The ratios for $\mathrm{Fe}$ and $\mathrm{Mn}$ are 7 and 9 , respectively.

In some of the crusts there is less $\mathrm{Fe}$ or Mn than in some of the oxidized surface muds. For instance, the three crusts lowest in Fe range from 5.9 to $8.5 \%$, while the five oxidized muds range from 5.1 to $8.3 \%$. Likewise, the two crusts lowest in Mn, with 2.3 and $1.4 \%$, contain almost the same concentrations as the two richest oxidized muds. The crusts are poorer in organic matter than the muds, so that even when their $\mathrm{Fe}$ and $\mathrm{Mn}$ contents are similar, the crusts are cemented into recognizable aggregates, while the muds are loose and unconsolidated.

$\mathrm{Fe}$ and $\mathrm{Mn}$ are positivcly correlated in the large crusts, but the small crust pieces from Wray Castle Boathouse Bay (sample 765) deviate from this relationship, being by far the richest in $\mathrm{Fe}$ but intermediate in their Mn content. Their $\mathrm{Fe}: \mathrm{Mn}$ ratio is the highest in the eight samples of crust, at 5.5 ; and also closest to the average ratio of the oxidized muds, 6.6. In general, the samples rich in $\mathrm{Fe}$ and $\mathrm{Mn}$ have low $\mathrm{Fe}: \mathrm{Mn}$ ratios, between 1 and 2 ; while the samples poorest in these elements have $\mathrm{Fe}: \mathrm{Mn}$ ratios above 2. It appears that crust development involves a greater enrichment of $\mathrm{Mn}$ than of $\mathrm{Fe}$. According to Naumann (1922) and Ljunggren (1953), manganese crusts develop on primary iron concretions, and Goldberg and Arrhenius (1958) suggest that iron accumulations pave the way for the formation of marine manganese nodules. The Wray Castle Boathouse samples seem to conform to this hypothesis, with the small pieces yielding a high and the large crust a low $\mathrm{Fe}: \mathrm{Mn}$ ratio. In Scandinavia, the same lake may contain some oxidates dominated by $\mathrm{Fe}$ and others dominated by Mn (Ljunggren 1953).

Only four elements show a distinctly positive correlation with $\mathrm{Fe}$ and $\mathrm{Mn}$ in the crusts: C, S, P, and Mo. These arc biophile elements, which suggest some influence of organisms upon crust accumulation. The ratio of $\mathrm{Mn}$ to $\mathrm{C}$ increases as these elements increase in concentration, while the ratio of Fe to $\mathrm{C}$ exhibits only a slight tendency in this direction, owing to a high value for the small crust pieces richest in Fe.

The relationship between $P$ and $F e$, which is much closer than that between $\mathrm{P}$ and $\mathrm{Mn}$, is presumably due to precipitation of ferric phosphate or to adsorption of phosphate by ferric hydroxide incorporated in the crusts. The $\mathrm{Fe}: \mathrm{P}$ ratio varies generally between 54 and 70 , except for a single anomalous value of 27 for the Ferry House sample (781). The ratios in the muds average in the low twenties, probably owing to the presence of a good deal of organic phosphorus. 

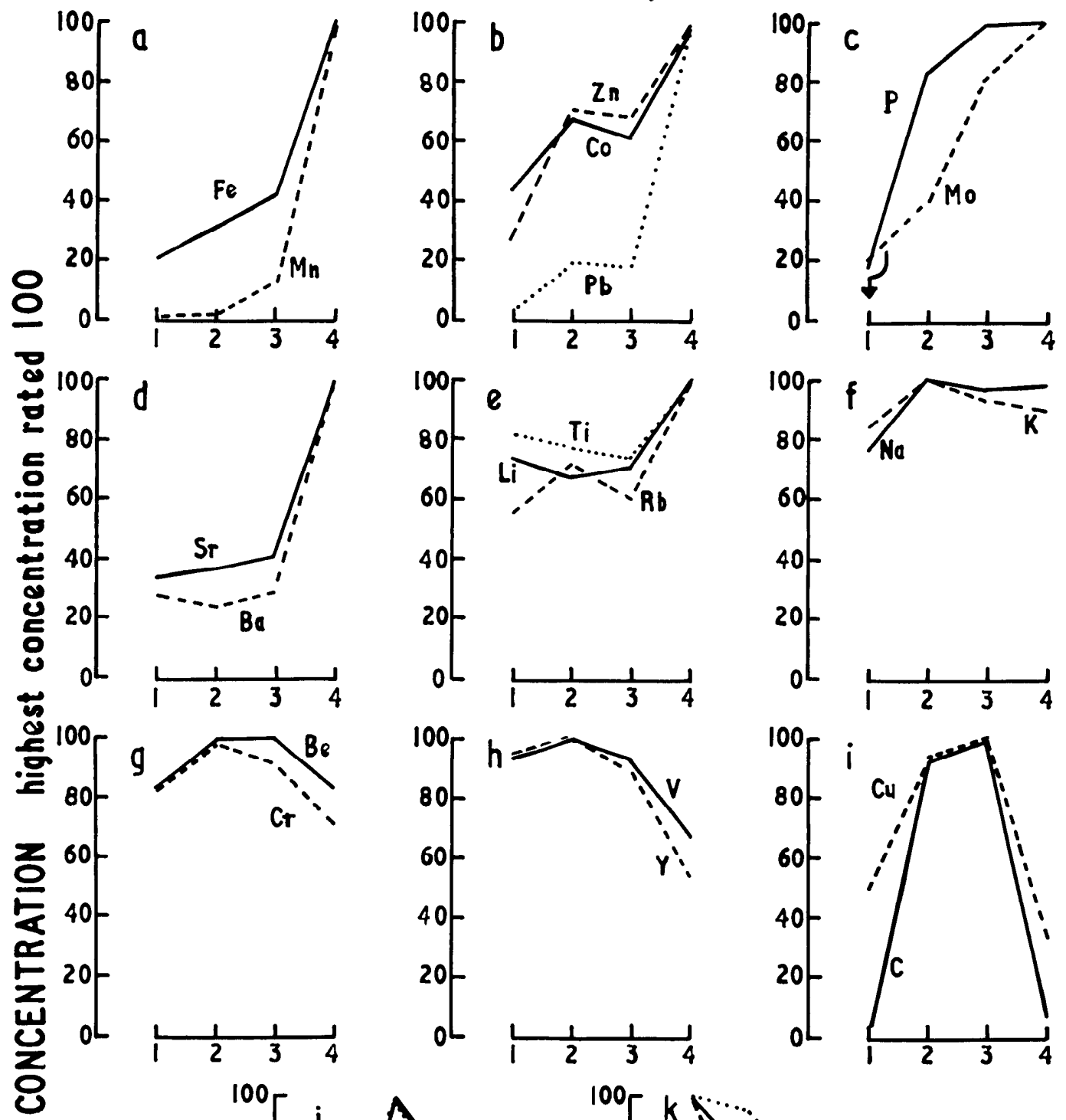

호흐을
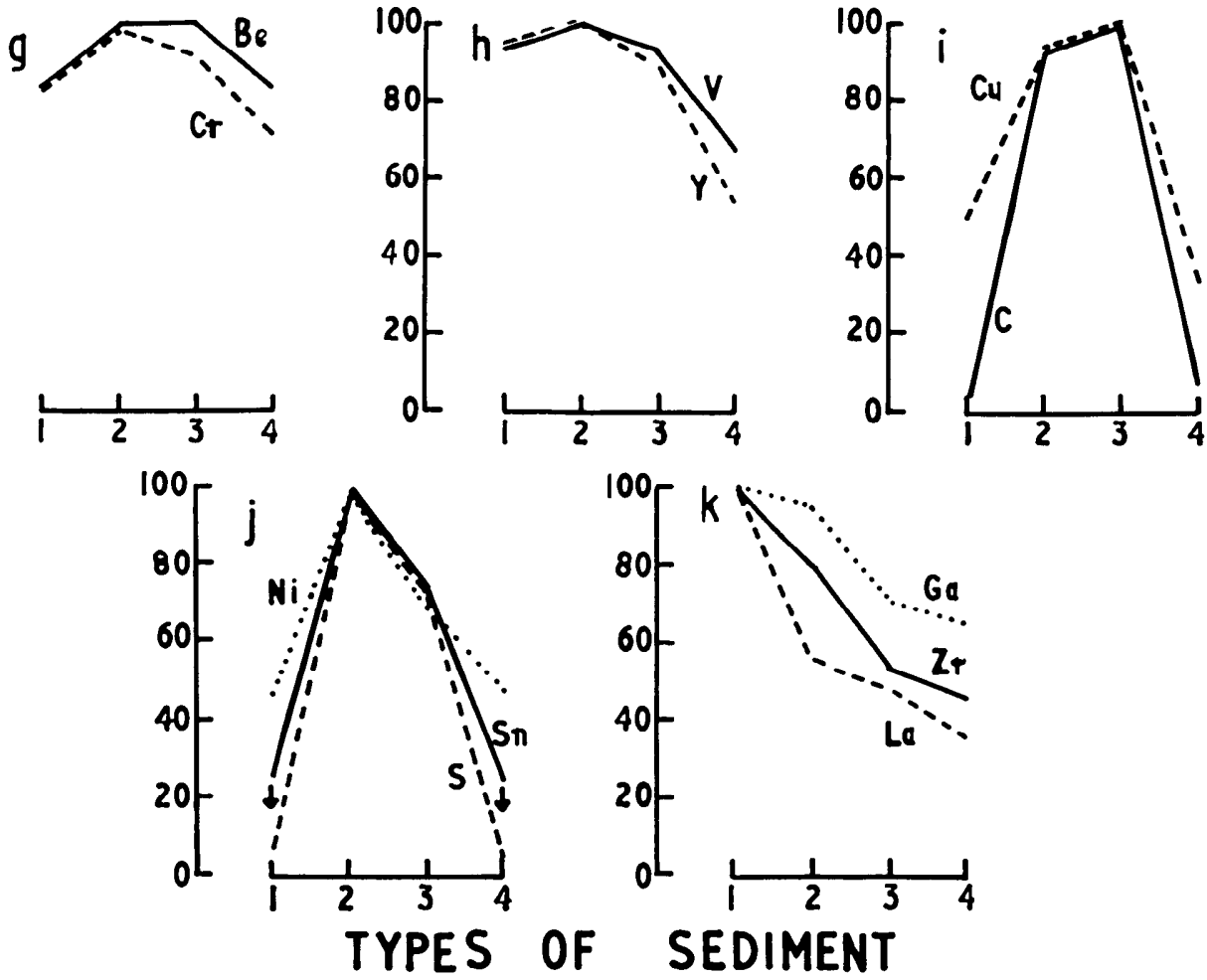

FIG. 1. Distribution of elements in (1) the white clay, (2) reducing mud, (3) oxidizing mud, and (4) oxidate crust. The sediment type exhibiting the highest concentration is rated at 100 , the concentrations in the others are shown as percentages of the highest. Downward pointing arrows indicate the percentage is not calculable, but is less than the indicated value. 
The Mo content of the crusts varies widely, with the three samples richest in $\mathrm{Fe}$ and $\mathrm{Mn}$ containing about $10 \mathrm{ppm}$, and the three poorest $<1 \mathrm{ppm}$. In comparison, the oxidized surface muds range from 1 to 6 ppm. How Mo accumulates in the oxidized sediments is not entirely clear, but the fact that both Mo and Mn are considerably more abundant in Windermere than in Esthwaite muds, while $\mathrm{Fe}$ is much the same in both, suggests that Mo follows Mn preferentially according to general geochemical expectation (Goldschmidt 1954).

Most of the elements analyzed in the crusts yield negative correlations with the amounts of $\mathrm{Fe}$ and $\mathrm{Mn}$ accumulated in them. Among the elements exhibiting the most marked declines are $\mathrm{Rb}, \mathrm{Li}, \mathrm{V}, \mathrm{Ga}$, and $\mathrm{Zr}$, some of the elements that are also most variable in concentration. These reach exceptionally low levels in the iron-rich crusts from the Wray Castle Boathouse Bay. Lesser decreases occur in $\mathrm{Cr}, \mathrm{Ti}, \mathrm{Y}$, $\mathrm{Cu}, \mathrm{Ni}, \mathrm{Na}$, and $\mathrm{K}$.

Among the elements not showing definite correlations with $\mathrm{Fe}$ and $\mathrm{Mn}$ accumulations are $\mathrm{Pb}, \mathrm{Zn}, \mathrm{Ba}, \mathrm{Sr}, \mathrm{Co}$, and $\mathrm{Be}$. The first three of these are abundant in the Ullswater crusts and in the sample believed to be from Ash Landing in Windermere, while the next two show a less marked tendency in the same direction. Accessory minerals rich in $\mathrm{Pb}, \mathrm{Zn}$, and $\mathrm{Ba}$ occur rather locally in the Lake District, and any oxidate crusts formed in the vicinity of such mineral occurrences may be expected to scavenge these elements by sorption processes (Smith 1960). It is noteworthy that Pb, $\mathrm{Zn}$, and to a lesser degree $\mathrm{Ba}$ are present in much greater abundance in the Lake District crusts and muds than in Scottish soils or the lithosphere (Table 2). Among elements which have lower concentrations in the crusts and muds than in Scottish soils or the lithosphere are $\mathrm{Sr}, \mathrm{Rb}, \mathrm{Cr}, \mathrm{V}, \mathrm{Cu}, \mathrm{Ni}$, and $\mathrm{Zr}$.

The relatively high contents of $\mathrm{Ba}$ in the oxidate crusts cannot be due entirely to barite formation, since the corresponding sulfur concentrations are too low. However, it is probable that any sulfate released during oxidation of organic matter in the vicinity of the crusts would form barite.

\section{DISCUSSION}

\section{Comparison of Esthwaite and Windermere sediments}

In spite of the fact that Windermere drains mostly hard volcanic rocks while Esthwaite receives most of its drainage off softer sedimentary slates and grits, there is slight difference between the muds of Windermere and Esthwaite Water in their concentrations of most elements. Esthwaite muds are notably poorer in $\mathrm{Mn}$ and $\mathrm{Mo}$, probably because of summer reduction of the profundal mud surface, where both elements tend to accumulate. This reduction no doubt allows Mo as well as Mn to escape from the surface of the mud into the bottom waters, and eventually to the outflow following autumnal breakdown of thermal stratification (Mackereth 1959). The profundal Esthwaite muds sampled in October were richer in $\mathrm{Mn}, \mathrm{Mo}$, and $\mathrm{Fe}$ than those sampled in November. The former, collected shortly after the restoration of isothermal circulation, appeared more oxidized, judging by their color. Iron, although released to the bottom waters of Esthwaite during summer, is not so easily kept in solution (Mortimer 1941-1942; Hutchinson 1957), and does not appear to be lost from the lake to the same extent as are Mn and Mo.

Silver is apparently more concentrated in Windermere than in Esthwaite mud. However, the above escape mechanism seems unlikely to operate for Ag, because this element is not enriched at the surface as are $\mathrm{Mn}$ and Mo.

The element most enriched in Esthwaite mud as compared with Windermere is sulfur. Carbon is similar in the mud samples from both lakes (although collections at other times suggest that Esthwaitc muds are on the average richer in this element), and so the $\mathrm{C}: \mathrm{S}$ ratio is much lower (22) in Esthwaite than in the Windermere muds (30). The low Esthwaite ratio undoubtedly reflects a greater degree of reduction in the mud as a whole (Mortimer 1941-1942), 
which both inhibits the oxidative breakdown of organic sulfur compounds and strengthens the fixation of inorganic sulfur as ferrous sulfidc.

It thus appears that while there are appreciable differences between the muds of the two lakes in four elements, the remaining 23 are much the same in both.

\section{Factors influencing accumulation of elements}

While enrichment of a given element in any sediment may be affected by a variety of environmental factors, it is possible to distinguish certain general tendencies in the data of Table 2 and Fig. 1.

A few elements are more concentrated in the organic muds than in the inorganic clays and crusts, the major ones being $\mathrm{C}$ and $\mathrm{S}$. The metals $\mathrm{Cu}, \mathrm{Sn}$, and $\mathrm{Ni}$ are also in this group, and organic complexing of metals may be involved. For example, porphyrins, well known in lake sediments (Vallentyne 1960), complex readily with $\mathrm{Ni}$ and $\mathrm{Cu}$ under certain conditions, but not with $\mathrm{Co}$; and $\mathrm{Cu}$ and $\mathrm{Ni}$ are higher in the muds than in the oxidate crusts, in contrast to Co (Table 2). Sn and Ni resemble $\mathrm{S}$ in being slightly more abundant in the reduced than in the oxidized muds. Precipitation of these metals as sulfides in the reduced phase may be responsible for this difference. $\mathrm{Sn}$ is much higher in the lake muds than in the lithosphere.

The effects of oxidation are manifested by $\mathrm{Fe}$ and more particularly by $\mathrm{Mn}$, both elements being strongly enriched in the oxidized sediments. The greater mobility of $\mathrm{Mn}$ is probably responsible for its enrichment relative to $\mathrm{Fe}$ in aquatic plants from Windermere, which are usually rich in both elements ( $\mathrm{Fe}$ averaging $1,500 \mathrm{ppm}$ and Mn 1,420 ppm dry weight, Mayer and Gorham 1951). The $\mathrm{Fe}: \mathrm{Mn}$ ratio for the plants is only 1.1 , in contrast to ratios of 5.4 and 21 for the oxidized and reduced Windermere muds, respectively. The ratio for the white glacial clay is highest of all80.

The accumulation of a number of other elements in the oxidate crusts is probably due to the marked sorptive properties of the ferromanganese minerals, which allow them to scavenge various elements such as $\mathrm{Ba}, \mathrm{Sr}, \mathrm{Mo}, \mathrm{P}, \mathrm{Pb}, \mathrm{Zn}$, and Co where these are plentiful in the cnvironment. Krauskopf (1956) has shown that hydrated oxides of both $\mathrm{Fe}$ and $\mathrm{Mn}$ can adsorb positive as well as negative ions. The last five elements mentioned above also appear to be distinctly more concentrated in the organic deposits than in the white glacial clay.

The accumulative properties of a reducing environment are best shown by sulfur, which reaches its highest levels in the subsurface organic muds. Ni and Sn appear to follow $\mathrm{S}$ in these aquatic sediments. Although some $\mathrm{Fe}$ is trapped as $\mathrm{FeS}$ in the reduced muds, the amount of $S$ available is insufficient to tie up a large amount of $\mathrm{Fe}$ in this way, and in any case some $\mathrm{S}$ may be present in organic and elemental forms.

\section{Comparison of oxidate crusts from various environments}

The oxidate crusts from Windermere and Ullswater resemble the Swedish lake and stream ores whose chemistry has been investigated by Ljunggren (1953, 1955 $a$ and $b$ ), and the Finnish "bog" ores (apparently of freshwater origin) examined by Landergren (1948). They are also similar to the manganese nodules collected from the ocean bottom, which have been studied by Goldberg (1954), Dietz (1955), Riley and Sinhaseni (1958), Mero (1960) and Willis and Ahrens (1962). Manheim (1961) has studied similar nodules from the Baltic Sea. Table 3 presents the ranges of concentration for a number of elements analyzed in more than one of these oxidate deposits. ( $\mathrm{Fe}$ and $\mathrm{Mn}$ ranges for Swedish samples represent only those samples analyzed for trace elements, the lake ores so analyzed being well below average in $\mathrm{Mn}$.)

A comparison of Swedish and English oxidates reveals that the Swedish lake ores are highest in $\mathrm{Fe}$, and the English ones lowest. The Swedish stream ores are highest in $\mathrm{Mn}$, and the Swedish lakes ores lowest (although samples not analyzed for trace elements range up to $37 \%$ ). Both types of Swedish ore are richer in $\mathrm{Sr}$ than the English oxidate crusts, while the man- 
TABLE 3. Elemental composition of ferromanganese concretions from different environments*

\begin{tabular}{|c|c|c|c|c|c|c|c|c|c|c|c|c|c|}
\hline \multirow{2}{*}{\multicolumn{2}{|c|}{ Element }} & \multicolumn{2}{|c|}{ English lakes } & \multicolumn{2}{|c|}{$\begin{array}{c}\text { Finnish } \\
\text { fresh waters }\end{array}$} & \multicolumn{2}{|c|}{ Swedish lakes } & \multicolumn{2}{|c|}{ Swedish rivers } & \multicolumn{2}{|c|}{ Baltic Sea } & \multicolumn{2}{|c|}{ Oceans } \\
\hline & & $\min$ & $\max$ & $\min$ & $\max$ & $\min$ & $\max$ & $\min$ & $\max$ & $\min$ & $\max$ & $\min$ & $\max$ \\
\hline $\mathrm{Fe}$ & $\%$ & 5.9 & 39.0 & 12.0 & 50.0 & 41.0 & 56.0 & 13.0 & 43.0 & & & 0.4 & 24.0 \\
\hline $\mathrm{Mn}$ & $" 1$ & 1.4 & 13.0 & 0.2 & 23.0 & 0.6 & 3.2 & 6.0 & 3.5 .0 & & & 11.0 & 50.0 \\
\hline $\mathrm{K}$ & $\%$ & 5.0 & 29.0 & $<0.4$ & 0.7 & 0.5 & I. 0 & 0.5 & 5.0 & & & 12.0 & 13.0 \\
\hline $\mathrm{Na}$ & $"$ & 1.8 & 10.0 & & & & & & & & & 18.0 & 22.0 \\
\hline $\mathrm{Ba}$ & $n$ & 0.8 & 8.0 & & & 0.1 & 2.0 & 0.5 & 5.0 & & & 2.6 & 3.6 \\
\hline $\mathrm{P}$ & it & 1.0 & 6.2 & & & & & & & 1.0 & 10.0 & 1.2 & 20.0 \\
\hline $\mathrm{Ti}$ & $" 1$ & 1.0 & 6.0 & $<0.1$ & 10.0 & & & & & & & 0.3 & 14.0 \\
\hline $\mathrm{Zn}$ & $"$ & 0.3 & 3.0 & & & & & & & 0.1 & 0.3 & 3.0 & 3.8 \\
\hline $\mathrm{Pb}$ & ppm & 30 & 8,000 & & & & & $<30$ & 80 & 100 & 300 & 25 & 3,500 \\
\hline$S$ & "1 & 50 & 480 & & & & & & & & & $5,500(1$ & sample) \\
\hline $\mathrm{Zr}$ & 11 & 10 & 150 & & & & & & & & & 18 & 220 \\
\hline $\mathrm{Rb}$ & 11 & 1 & 150 & $<10$ & 10 & $<1$ & & $<100$ & 500 & & & & \\
\hline $\mathrm{Sr}$ & 11 & 25 & 100 & & & $<100$ & 800 & $<100$ & 1,000 & & & 430 & 1,100 \\
\hline V & 11 & 2 & 100 & & & 50 & 100 & 30 & 100 & 3 & 10 & 270 & 850 \\
\hline $\mathrm{Li}$ & 11 & $<\overrightarrow{1}$ & 80 & $<5$ & 40 & & & & & & & & \\
\hline Co & 11 & 20 & 60 & 60 & 300 & $\leqq 10$ & 50 & 30 & 600 & 20 & 60 & 70 & 20,000 \\
\hline $\mathrm{Y}$ & $" 1$ & 10 & 60 & & & & & & & & & 10 & 20 \\
\hline $\mathrm{Cr}$ & $"$ & 4 & 60 & & & & & $<20$ & 30 & & & $<5$ & \\
\hline La & $" 1$ & 20 & 40 & & & & & & & & & 60 & 170 \\
\hline $\mathrm{Ni}$ & $" 1$ & 10 & 40 & $<10$ & 100 & $\leqq 10$ & 50 & $\leqq 10$ & 100 & 30 & 100 & 290 & 16,000 \\
\hline $\mathrm{Ga}$ & $" 1$ & 1 & 25 & & & & & & & & & 4 & 15 \\
\hline $\mathrm{Cu}$ & $" 1$ & $<5$ & 20 & & & & & & & 30 & 100 & 160 & 18,000 \\
\hline Mo & 11 & $<1$ & 10 & $<50$ & 60 & & & $<30$ & 30 & & & 190 & 2,000 \\
\hline $\mathrm{Be}$ & 11 & $<5$ & 8 & $<10$ & 10 & & & $<10$ & 50 & 1 & 3 & & \\
\hline Sn & 11 & & & & & & & & & 1 & 3 & 160 & 230 \\
\hline $\mathrm{Ag}$ & $" 1$ & & & & & & & & & & & 10 & \\
\hline$B$ & $" 1$ & & & 20 & 40 & & & 10 & 20 & 100 & 300 & 70 & 500 \\
\hline
\end{tabular}

* Elements are given in order of maximum abundance in the English samples.

ganiferous stream ores are also richer in Co. $\mathrm{Ni}, \mathrm{Sr}$, and $\mathrm{Ba}$ tend, like $\mathrm{Co}$, to be more concentrated in the manganiferous stream ores, but these correlations with $\mathrm{Mn}$ are not evident in the English crusts. The Swedish ores are much lower in $\mathrm{K}$ than the English crusts, and do not show the striking enrichment of $\mathrm{Pb}$ exhibited by three English samples. There is a marked positive correlation between radioactivity and $\mathrm{Mn}$ content in the Swedish ores (Ljunggren 1955a).

The freshwater Finnish ores are also notably richer in Fe than the English crusts, and have a much wider range of $\mathrm{Mn}$ content. They are poorer in $\mathrm{V}, \mathrm{Cr}$, and the alkalis, but are relatively rich in Co. As in the English crusts, but in contrast to the Swedish ores, there is no correlation between $\mathrm{Co}$ or $\mathrm{Ni}$ and $\mathrm{Mn}$.

It is of special interest to compare freshwater ferromanganese concretions with those of the sea. In Fig. 2, where a distinctly inverse relationship is evident between $\mathrm{Fe}$ and $\mathrm{Mn}$, it is clear that $\mathrm{Fe}$ predominates in the freshwater crusts and $\mathrm{Mn}$ in the marine nodules. The median values for the Fennoscandian freshwater oxidates are $31 \% \mathrm{Fe}$ and $13 \% \mathrm{Mn}$, while for the marine oxidates the medians are $13 \%$ $\mathrm{Fe}$ and $22 \% \mathrm{Mn}$. This difference presumably reflects the general tendency of $\mathrm{Fe}$ to precipitatc more rcadily than $\mathrm{Mn}$ from weathering solutions under oxidizing conditions (Krauskopf 1957), so that earlier deposits tend to be enriched in Fe and later deposits in Mn. Three of the crusts from the English lakes are anomalous in being comparatively low in both $\mathrm{Mn}$ and $\mathrm{Fe}$. Two of these (783 and 784) clearly show much clastic mineral sediment cemented into them.

A number of elements are strikingly more abundant in the deep-sea oxidates than in those of freshwater origin, namely Mo, V, $\mathrm{Ag}, \mathrm{Cu}, \mathrm{Sn}, \mathrm{Ni}$, and B. Co is also very high in many of the marine oxidates. Such enrichments probably reflect the strong sorptive properties of the hydrated oxides of $\mathrm{Fe}$ and $\mathrm{Mn}$, coupled with a very slow rate of formation that has allowed a high degree of sorptive incorporation of trace elements. Manheim (1961) has remarked that manganese nodules from the Baltic Sea have much lower trace element concentrations, prob- 


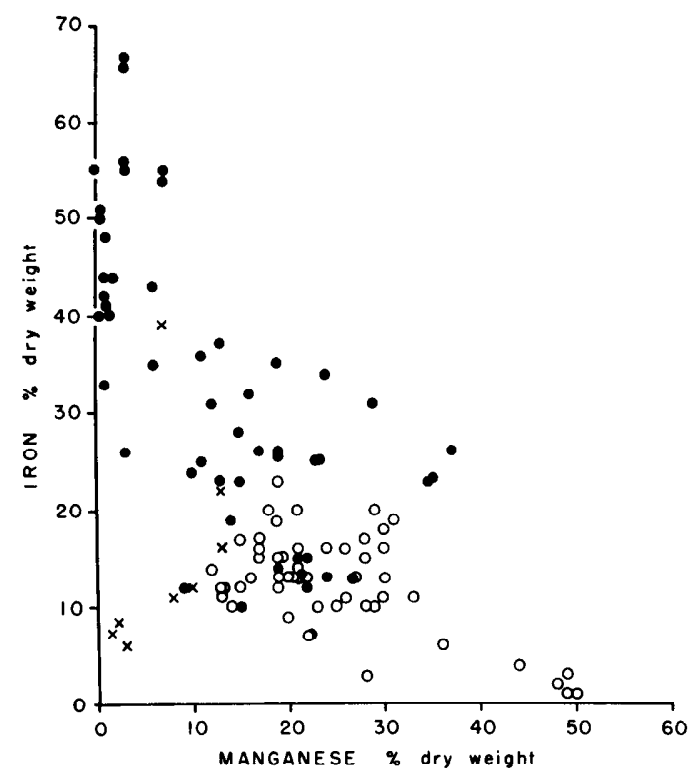

FIG. 2. Manganese and iron in oxidate concretions. Solid circles-Fennoscandian freshwaters, crosses-English lakes, open circles-sea.

ably because they have formed more rapidly than the deep-sea nodules. The freshwater oxidate crusts have likewise grown much more rapidly than the marine nodules. However, the degree of enrichment of $\mathrm{Pb}$ and $\mathrm{Zn}$ in certain crusts from the English lakes is comparable to that of marine manganese nodules, presumably because of the exceptional local abundance of these elements in an area where ore bodies are not uncommon.

Goldberg (1954) has claimed that, in marine manganese nodules, $\mathrm{Ni}$ and $\mathrm{Cu}$ correlate positively with $\mathrm{Mn}$; and $\mathrm{Co}, \mathrm{Ti}$, and $\mathrm{Zr}$ with $\mathrm{Fe}$. However, the $\mathrm{Cu}-\mathrm{Mn}$ and $\mathrm{Zr}-\mathrm{Fe}$ correlations are insecurely founded (Riley and Sinhaseni 1958). The Ni-Mn correlation is shown to some degree by the Swedish freshwater ores, but not by the Finnish or English oxidates. The Co-Fe correlation is, if anything, negative, rather than positive as in the marine nodules; and the same may be said of the Ti-Fe relationship. The Lake District crusts were the only freshwater samples analyzed for $\mathrm{Zr}$ and $\mathrm{Cu}$; the former shows a negative rather than a positive correlation with $\mathrm{Fe}$, and the latter tends, if anything, to be negatively correlated with Mn.

Willis and Ahrens (1962) have reported a distinct correlation betwecn $\mathrm{Ni}$ and $\mathrm{Cu}$ in Pacific manganese nodules, and it is also evident in the English lake crusts. However, in the freshwater samples both elements tend to be less abundant in the crusts richer in $\mathrm{Fe}$ and $\mathrm{Mn}$, contrary to the case in the ocean.

In conclusion, it appears that no geochemical regularities can be established over the whole range of ferromanganese oxidate deposits, for even the general inverse relationship between $\mathrm{Fe}$ and $\mathrm{Mn}$ is reversed in the series of English freshwater samples. Probably the most rewarding field for future investigation would be the detailed analysis of elemental abundance in water, sediments, and associated ferromanganese concretions within small areas. Analysis of crusts forming directly on rocks, and of the ambient waters, might be of especial interest.

\section{REFERENCES}

Burton, J. D., F. Culkin, and J. P. Riley. 1959. The abundances of gallium and germanium in terrestrial materials. Geochim. Cosmochim. Acta, 16: 151-180.

Carr, M. H., and K. K. Turekian. 1961. The geochemistry of cobalt. Geochim. Cosmochim. Acta, 23: 9-60.

Dietz, R. S. 1955. Manganese deposits on the northeast Pacific sea floor. Calif. J. Mines Geol., 51: 209-220.

Fleischer, M. 1953. Recent estimates of the abundances of the elements in the earth's crust. U.S. Geol. Surv., Circ. 285. 7 p.

Fröhlich, F. 1960. Beitrag zur Geochemie des Chroms. Geochim. Cosmochim. Acta, 20: 215-240.

GoldberG, E. D. 1954. Marine geochemistry. 1. Chemical scavengers of the sea. J. Geol., 62: 249-265.

—, ANd G. O. S. Arrhenius. 1958. Chemistry of Pacific pelagic sediments. Geochim. Cosmochim. Acta, 13: 153-212.

Goldschmid, V. M. 1954. Geochemistry. Clarendon Press, Oxford. 730 p.

Gorfam, E. 1958. Observations on the formation and breakdown of the oxidized microzone at the mud surface in lakes. Limnol. Oceanog., 3 : 291-298.

- 1960. Chlorophyll derivatives in surface muds from the English lakes. Limnol. Oceanog., 5: 29-33. 